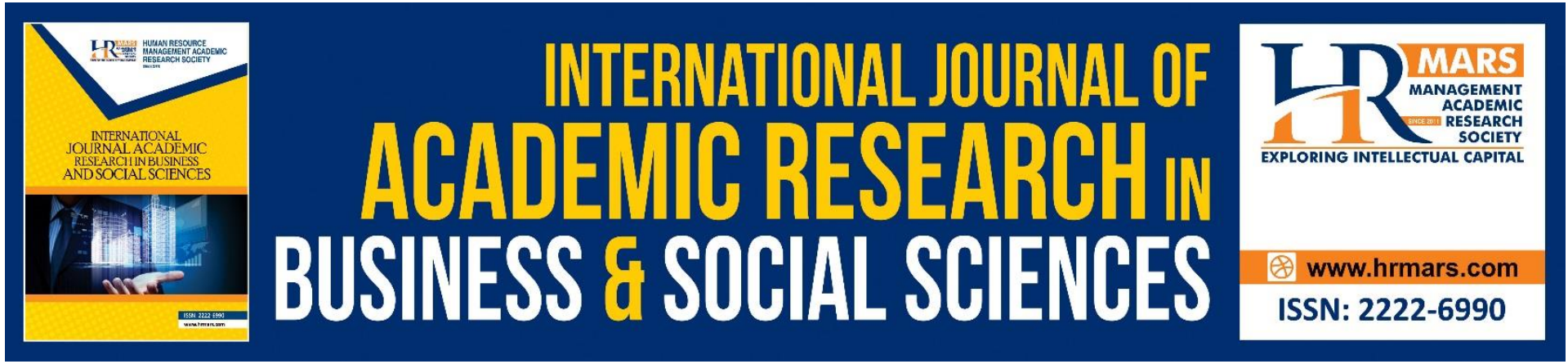

\title{
The Association between the Impacts of Telecommuting Work Arrangement and Employee Performance during Covid- 19 Pandemic: A Case Study in Private Sector
}

Syaza Fatehah binti Nizar, Rozihana binti Shekh Zain, Mohd Fazly bin Mohd Razali, Ima llyani binti Ibrahim \& Nik Azlina binti Nik Abdullah

To Link this Article: http://dx.doi.org/10.6007/IJARBSS/v11-i7/10161

DOI:10.6007/IJARBSS/v11-i7/10161

Received: 08 May 2021, Revised: 10 June 2021, Accepted: 27 June 2021

Published Online: 07 July 2021

In-Text Citation: (Nizar et al., 2021)

To Cite this Article: Nizar, S. F. binti, Zain, R. binti S., Razali, M. F. bin M., Ibrahim, I. I. binti, \& Abdullah, N. A. binti N. (2021). The Association between the Impacts of Telecommuting Work Arrangement and Employee Performance during Covid- 19 Pandemic: A Case Study in Private Sector. International Journal of Academic Research in Business and Social Sciences, 11(7), 257-267.

Copyright: (c) 2021 The Author(s)

Published by Human Resource Management Academic Research Society (www.hrmars.com)

This article is published under the Creative Commons Attribution (CC BY 4.0) license. Anyone may reproduce, distribute, translate and create derivative works of this article (for both commercial and non-commercial purposes), subject to full attribution to the original publication and authors. The full terms of this license may be seen

at: http://creativecommons.org/licences/by/4.0/legalcode

Vol. 11, No. 7, 2021, Pg. 257 - 267

Full Terms \& Conditions of access and use can be found at http://hrmars.com/index.php/pages/detail/publication-ethics 


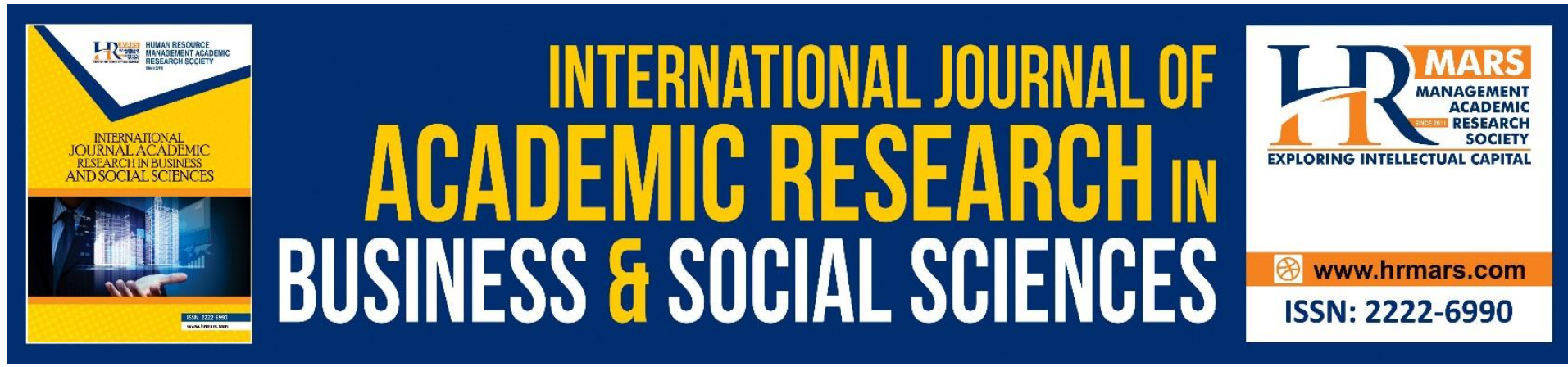

\title{
The Association between the Impacts of Telecommuting Work Arrangement and Employee Performance during Covid-19 Pandemic: A Case Study in Private Sector
}

\author{
Syaza Fatehah binti Nizar \\ Student, Faculty of Business and Management, Universiti Teknologi MARA, Perlis Branch, Arau \\ Campus, 02600 Arau, Perlis, Malaysia \\ Email: syazafatehah@gmail.com
}

\begin{abstract}
Rozihana binti Shekh Zain, Mohd Fazly bin Mohd Razali, Ima llyani binti Ibrahim \& Nik Azlina binti Nik Abdullah

Senior Lecturer, Faculty of Business and Management, Universiti Teknologi MARA,

Perlis Branch, Arau Campus, 02600 Arau, Perlis, Malaysia

Email: rozihana@uitm.edu.my,mohdfazly@uitm.edu.my, ilyani686@uitm.edu.my, nikazlina@uitm.edu.my
\end{abstract}

\begin{abstract}
The relevance of today's work arrangement that is now being questioned due to the current pandemic situation had driven the researcher to examine the relationship between the impacts of telecommuting work arrangement and employee performance during the Movement Control Order (MCO) due to COVID-19 pandemic. The telecommuting work arrangement has played a significant role in Malaysia nowadays and it has become one of the mechanisms to ensure business continuity. The study has adopted cross-sectional survey research design to examine the relationship between variables. The data was collected via online survey from 152 respondents that Work From Home (WFH) during Movement Control Order (MCO) in Northern Malaysia. The findings had revealed that all of telecommuting impacts particularly job autonomy; work-family balance and level of occupational stress have a significant relationship with employees' performance. Thus, it was indicates that majority of the respondents prefer telecommuting and are aware with the flexibility, and other benefits offered by it. The findings of the study should assist the employers to enhance the level of acceptance of this unfamiliar working concept among Malaysian which eventually will lead to the achievement of excellent performance in organization. It also serves as useful information to the organization and the policymakers who considered implementing this new working concept.
\end{abstract}

Keywords: Telecommuting Work Arrangement, Work From Home (WFH), Movement Control Order (MCO), Employee Performance, Job Autonomy, Work-Family Balance, Work Productivity, Occupational Stress, Covid-19 Pandemic. 


\section{Introduction}

A cluster of pneumonia cases of unknown cause was reported on 31 December 2019 in Wuhan, Hubei Province, China (Singhal, 2020). On 9 January 2020, China CDC reported a novel corona virus as the cause of this outbreak, corona virus disease 2019 (COVID-19). Formerly known as '2019 novel corona virus' or '2019-nCoV', the COVID-19 is a new virus related to the same family of viruses as Severe Acute Respiratory Syndrome (SARS) and certain types of common cold (Shereen et al., 2020). People that have been infected with the COVID-19 virus will likely to develop mild to moderate respiratory illness and recover without requiring special treatment while those with underlying medical problems such as cardiovascular disease, diabetes, chronic respiratory disease, and cancer are more likely to develop serious illness (Zhang et al., 2020).The World Health Organization (WHO) declared that COVID-19 was a pandemic when it became clear that the disease was serious and that it was spreading rapidly across a wide area.

The first case detected in Malaysia was on 25th January 2020, when 3 local who had previously had close contact with an infected person in Singapore returned to the country (Elengoe, 2020). To date (13 ${ }^{\text {th }}$ June 2021) a total of 657,508 cases of COVID-19; 3908 cases of deaths and 73,324 active cases have been reported in Malaysia (MOH, 2021). Due to the spike of the cases in Malaysia, Malaysian government has implemented restricted Movement Control Order (MCO). This was part of Malaysia government's initiative to curb the spreading of the virus. With the restriction movement order in place which lead to the closure of many public and private sectors, majority of Malaysian are required to work from home if possible (Mumin, 2020).

One of government initiative to curb the spread of Covid-19 is an adjustment to traditional working culture to telecommuting (Chang et al., 2020). Even though telecommuting work arrangement has been implemented by many countries it is still consider as a new concept to Malaysian culture (Fazrida et al., 2018). However, The Movement Control Order (MCO) leaves many organizations with no option but to implement this type of working concept to ensure business continuity (Mumin, 2020). The concern is regarding the readiness and willingness of employers to implement this strategy in their organization. This is because in Malaysia, many employers are still questioning whether telecommuting will lead to better employee and organizations' performance (Fazrida et al., 2018). Although telecommuting offers several benefits, the implementation of it during this situation may present additional challenges (Mumin, 2020). Therefore, this study intends to examine whether telecommuting work arrangement (job autonomy, work-family balance, work productivity and level of occupational stress) provide the positive or adverse impacts to the performance of employees which will provide preliminary information of the telecommuting implementation in Malaysian culture.

\section{Problem Statement}

Telecommuting work arrangement has been implemented in several countries which offer their employees flexibility in work and improve working experience. Malaysia on the other hand are still unfamiliar with the type of practice as it is still considered as the new working concept besides the lack of support from the local company itself (Fazrida et al., 2018). However, this situation has changed over the time. The year 2020 has brought significant changes to the global economy and the corporate world. Due to the seriousness of Coronavirus Pandemic, a large proportion of the workforce was told to remain home and continue to operate remotely if possible when the lock downs or stay-at-home measures came into effect (ILO, 2020). Under normal circumstances telecommuting may be an option in certain organization, however in situation such as the COVID-19 it may lead to involuntary telecommuting. Nevertheless it has proved to be a significant part of maintaining business continuity. 
Substantially, many local companies are overwhelmed by this situation due to the perception they hold on such practice and still questioning the significant impact that may be brought by telecommuting practice toward their employees as well as organization's performance (Mahdi, 2012). Previous study by (Fazrida et al., 2018) stated that married women with children favor the telecommuting practice as they have more flexibility in their work and have the opportunity to balance their responsibilities, however, that is prior to Covid-19 pandemic. Recent survey conducted by Eurofound, revealed that there is an additional challenges present for working parents and cares due to the recent Covid-19 situation. Such employees find it difficult to manage their job and care responsibilities and present additional challenges in maintaining their work-life balance. Even though there has been many study conducted on telecommuting previously, however those studies are limited prior to COVID-19 pandemic. The lack of awareness towards the impacts of telecommuting might lead to performance failure among employees (Fazrida et al., 2018). Hence, the current study aims to address these limitations by examining the possible impacts of telecommuting toward employee performance during COVID-19 pandemic.

\section{Literature Review \\ Employee Performance}

Employee performance can be defined as how the employee carry out their job duties and task required by their employer or organization. Employee performance usually affects the success of an organization. Employee performance is the outcome of work leading to achievement or failure of any organization (WOLOR et al., 2020).

According to Pradhan \& Jena (2016), employee performance refers to the achievement of an individual's work by making the necessary work effort to achieve a meaningful work, engaged profile, and compassionate co-workers. Employee performance is measured in terms of quality, quantity of work, responsibility, implementation of the task and initiative taken (Maulidiyah, 2019). Performance is an important mechanism to clearly define the objectives and performance standards, in order to motivate individual performance to ensure organization sustainability (Muda et al., 2014).

\section{Telecommuting}

Telecommuting refers to work arrangement that allows employee to perform and carry out their work at remote location and away from their office, often working from home or close from their home. Rather than performing work at office, this work arrangement enables employee to keep in connection with their employer and co-workers through technological advancement. Telecommuting refers to the ability of employees to work from home and connect with their superior and colleagues using personal computers, mobile devices and software (Karia et al., 2003).

Telecommuting is also referring to the use of telecommunications technologies that enable employees to perform their duties remotely, away from their workplaces such as coffee shops, library or usually at the employee's home with the consent of employer Ye, L. (2012). Telecommuting offers employee with several benefits that will enhance their working and personal life.

Onyemaechi et al. (2018) posit that telecommuting allows more flexibility in employee's schedule which helps them to respond quickly in case of unexpected events. Furthermore, (Fazrida et al., 2018) stated that telecommuting offers opportunity for working parents to balance their work and personal needs. 


\section{Job Autonomy}

Job autonomy can be defined the degree to which a job provides employee with significant freedom, independence and discretion in determining their working schedule and how they wish to carry out task given (Saragih, 2011). Job autonomy can be classified into two main dimensions which is having autonomy over work schedule and work approach (Khoshnaw \& Alavi, 2020). Rizwan et al (2014) stated that job autonomy is likely to offer employees the freedom over their job, which is likely help in reducing stress caused by the need to present certain emotions when performing their job.

In other word, autonomy is necessary for employee when telecommuting since they will perform job away from their employer. It indicates that they have the choice in their working aspect and that they are the source of their own action. Job autonomy also contributes in employee performance because having autonomy allows them to perceive that they are capable and more resourceful when performing their task (Saragih, 2011). Therefore, from the psychological aspect, this will increase motivation in performing their job which eventually lead directly to higher performance (Fazrida et al., 2018).

\section{Work-Family Balance}

Work family balance refers to the situation which one is able to attend to both personal and works need without any conflict. Work life balance can be defined as working policy that help employee to strike a balance between work and non-work responsibilities (Munusamy, 2016). Consistent with Greenhaus et al. (2003), the work family balance is as an extent to which an individual is equally engaged and satisfied within work and family responsibilities. Past study by Liu et al. (2019) indicates work-family balance as the absence of work-family conflict.

The flexibility in telecommuting has become one of the contributing factors to workfamily balance because it provides teleworkers with flexibility in terms of time and place. Dual career parents may be greatly appreciated of that flexibility because it allows them to stay at home to take care of their children or parents as well as performing their job (Fazrida et al., 2018). According to (Tony, 2011) work-family balance can be achieved through telecommuting because it gives employee flexibility over time so that they can engage in other activities, such as spending time with their families, leisure activities and other needs.

\section{Level of Occupational Stress}

Occupational stress refers to progressive stress experienced by individual at work due to the commitments, situations, environment or other pressures of the workplace. Robbins and Judge (2008) reveals that over workload, less capable supervisors, limited time at work, lack of responsibility, ambiguity of roles, conflict arising at workplace may be the contributing factors of occupational stress. Occupational stress may occur when one's resources are inadequate to meet the demands and pressures of the situation (Kazmi et al., 2008). Stress is not necessarily negative; it could be positive but up to a certain extent. According to Irawanto et al. (2015), stress can bring either positive or negative effect on employee performance and it depends on the level of stress experienced by that employee.

Telecommuting is one of the mechanisms that can be used to reduce occupational stress. Since telecommuting does not required employee to commute to their offices, this could be help to decrease stress related to workplace condition (Mendoza, 2020). This is consistent with past study conducted by Fazrida et al. (2018), telecommuting can help reduced occupational stress since employee are given the opportunity to perform work from home, having flexibility in terms 
of time, less interactions with colleagues and additional meetings and project which lead to less work conflict.

\section{Research Framework}

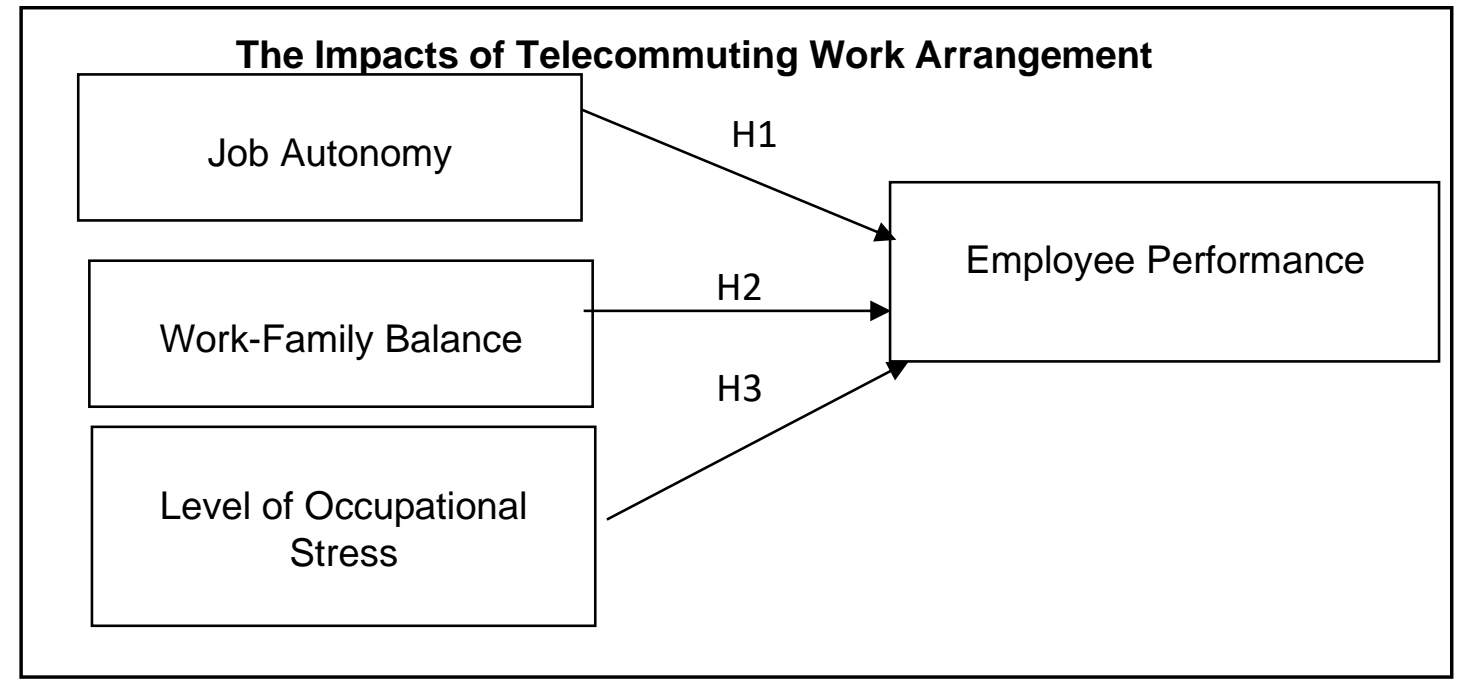

Figure 1 Theoretical Framework

(Sources: Fazrida et al., 2018)

\section{Research Methodology}

This study focused on the employees who engaged in the telecommuting practices. The respondents were selected from different private companies that located in Northern Malaysia. Using convenience sampling technique, the sample was chosen from random property and development companies that involved 152 employees. At the date of data collection, since Malaysia is still under Movement Control Order (MCO), therefore the survey was done via online that encompasses of two languages which is English and Malay to accommodate respondent's preference. It consists of six sections with 34 items that adopted from previous scholars. To measure the items, Likert scale of 1 to 5 (from the lowest value of 1 indicate to "strongly disagree" and the largest value of 5 indicate to "strongly agree") were used to collect information including the demographic backgrounds and telecommuting experiences. The telecommuting impacts were employed to measure employees' performance when working from home during Covid-19 pandemic.

\section{Findings Analysis}

Table 1 provides the summary of descriptive analysis such as mean, minimum; maximum and standard deviation that obtained for interval-scaled independent and dependent variables. All variables were taped on a five-point scale. The means for all study variables are above 4, indicating that majority of the respondents agreed that the three impacts of telecommuting have a significant effect towards employee performance. The values of minimum of 1.00 for all variables revealed that certain respondents disagree that there is a relationship between the three impacts of telecommuting toward their performance. The means for all variables are perceived at the range between 4.11-4.27. 
Table 1 Descriptive Analysis

\begin{tabular}{lcccc}
\hline \multicolumn{1}{c}{ Variables } & Minimum & Maximum & Mean & Std. Deviation \\
\hline Job Autonomy & 1.00 & 5.00 & 4.25 & .80840 \\
Work-Family Balance & 1.00 & 5.00 & 4.17 & .79550 \\
Level of Occupational Stress & 1.00 & 5.00 & 4.27 & .83066 \\
Employee performance & 1.00 & 5.00 & 4.11 & .89386. \\
\hline
\end{tabular}

Table 2 presented the result of reliability analysis. A value that is close to 1 indicates high reliability. As can be seen, Cronbach's Alpha for all variables is above 0.90 which remarks as an excellent. Thus, it indicates that all items measure is reliable and appropriate.

Table 2 The Reliability Analysis

\begin{tabular}{lcc}
\hline \multicolumn{1}{c}{ Variables } & No. of items & Cronbach's Alpha \\
\hline Job Autonomy & 5 & 0.94 \\
Work-Family Balance & 6 & 0.93 \\
Level of Occupational Stress & 4 & 0.94 \\
Employee performance & 5 & 0.96 \\
\hline
\end{tabular}

Results of correlation analysis are presented in Table 3. As stated, job autonomy is correlated positively and significantly with reliability $(r=.88, p<.01)$, work-family balance $(r=.85),(p<.01)$ and the level of occupational stress $(r=.87),(p<.01)$ respectively. Thus the results of correlation analysis provide initial support for the study hypotheses.

Table 3 Correlation Analysis

\begin{tabular}{lcccccc}
\hline \multicolumn{1}{c}{ Variables } & Mean & SD & 1 & 2 & 3 & 4 \\
\hline Job Autonomy & 4.2518 & .80840 & 1 & & & \\
Work-Family Balance & 4.1741 & .79550 & $.801^{* *}$ & 1 & & \\
Level of Occupational Stress & 4.2679 & .83066 & $.791^{* *}$ & $.871^{* *}$ & 1 & \\
Employee performance & 4.1116 & .89386 & $.875^{* *}$ & $.849^{* *}$ & $.869^{* *}$ & 1 \\
\hline
\end{tabular}

In Table 4, the result of multiple regressions is presented. The whole model explained $85 \%$ of the variance in employee performance. All of three independent variables which are job autonomy, work-family balance and occupational stress significantly predicted employee performance with $(\beta=.45, p>0.1),(\beta=.17, p>0.1)$ and $(\beta=.36, p>0.1)$ respectively. Hence, all the study hypotheses were accepted.

Table 4 Multiple Regression Analysis

\begin{tabular}{lcl}
\hline \multicolumn{1}{c}{ Variables } & $\beta$ & Sig. \\
\hline Job Autonomy & .449 & .000 \\
Work-Family Balance & .173 & .033 \\
Level of Occupational Stress & .363 & .000 \\
Adjusted R Square & .85 & \\
\hline
\end{tabular}

\section{Discussions}

The results of the findings indicate that telecommuting is one of the mechanisms that help to increase employee performance. The study found that majority of respondent prefer working from home during Covid-19 pandemic and when Movement Control Order (MCO) 
was in place. The upsurge in job autonomy leads to better employee performance and it was consistent with previous findings that posit the job autonomy has a significant relationship to employee performance since having a certain amount of autonomy in their work allows them to be more creative and flexibility in their decision-making (Fazrida et al., 2018). Job autonomy allow employee to have more control over their work which mean they are given good extent of freedom in determining to carry out and accomplish the task given. The flexibility given to them leads to a better performance since the employees feel that they are capable in their work. Similar to a study conducted by Saragih (2011), when employee perceived themselves capable, it will motivate them to do their best and accomplish the task given which eventually leads to better performance.

This study also found that employee who engaged in telecommuting experience a great balance between their work and non-work responsibilities. When organization implement telecommuting work arrangement in work place, it helps employee to finds more balance towards their personal and work demand. This was supported by previous findings by Aziz-Ur-Rehman \& Siddiqui (2019) that stated when employees are offer with more flexibilities in their work schedule it reduced work-life conflict because they are able to attend to both needs. Working from home during this pandemic has helped working parents to have a greater balance in their work and family responsibilities. According to Wolor et al. (2020), reduced in work-life conflict have a significant impact toward employee attitude, behavior and performance at work. Based on the results, telecommuting has a positive effect on workfamily balance especially for working parents who have to juggle between work and family responsibilities.

Moreover, a study revealed by Mann \& Holdsworth (2003) found that when individual engaged in telecommuting, it shows low level of occupational stress. Occupational stress may arise when employee are unable to cope with hectic situation or work demand. The low level of occupational stress reduce due to the time save in commuting and they have more control over their personal time. It was highlight that one of telecommuting benefits is the reduction in commuting time also decrease employees' level of stress which has a positive impact on their performance. Moreover, a study conducted by Fazrida et al (2018) revealed that occupational stress has a significant impact on employee performance. Hence reducing occupational stress among employees is crucial as it affect the quality of work. Since then, telecommuting provides opportunity to reduce occupational stress among employee.

\section{Conclusions}

In conclusion, this paper has discussed three key areas of telecommuting work arrangement and employee performance during the Movement Control Order (MCO) due to COVID-19 pandemic. All of three independent variables which are job autonomy, work-family balance and occupational stress significantly predicted employee performance with $(\beta=.45$, $p>0.1),(\beta=.17, p>0.1)$ and $(\beta=.36, p>0.1)$ respectively. Hence, all the study hypotheses were accepted. Though, this pandemic situation as well as Movement Control Order (MCO) may be the primary reason of involuntary implementation of telecommuting work arrangement in many organizations in Malaysia. Nevertheless, telecommuting work arrangement is relevant to be adapted in organization to ensure business continuity. However telecommuting still consider as new concept among Malaysian working culture (Fazrida et al., 2018). This indicates that future study on this area is still much needed to understand the long-term impact of teleworking post Covid-19 pandemic given the likely increasing spread of this work practice globally. One area of policy where planning and implementation is an absolute 
necessity is guidance into adapting to remote online work. We also need to explore the organizations and individuals confronting to the changes and challenges in coping up in this testing time. The issues of individual workers' mental and physical health and to develop recommendations for employers and employees to optimize workers' health as well its productivity. There are growing concerns about the level of stress accommodating the new extensive mass telecommuting experience during Movement Control Order (MCO). It leads to such as isolation and the loss of meeting co-workers, which it is essential in the work place. The performance appraisal system must be changed to suits the new era of working post Covid-19. Many companies are at chaos during performance review and strive hard to last minute changes to their performance measures and rewards guidelines. A study need to focus not only how to perform the job but as well as to evaluate effectively the employees performance by setting realistic fair performance goals and significant to the uncertain future environment.

\section{Acknowledgement}

Thank you to all respondents for their involvement during the collection of data since this study had been done during the pandemic of COVID-19 and also Movement Control Order (MCO).

\section{References}

Aziz-Ur-Rehman, M., \& Siddiqui, D. A. (2019). Relationship Between Flexible Working Arrangements and Job Satisfaction Mediated by Work-Life Balance: Evidence From Public Sector Universities' Employees of Pakistan. International Journal of Human Resource Studies. https://doi.org/10.5296/ijhrs.v10i1.15875

Chang, Y., Chien, C., \& Shen, L. F. (2020). Telecommuting during the coronavirus pandemic: Future time orientation as a mediator between proactive coping and perceived work productivity in two cultural samples. Personality and Individual Differences. https://doi.org/10.1016/j.paid.2020.110508

Elengoe, A. (2020). COVID-19 outbreak in Malaysia. In Osong Public Health and Research Perspectives. https://doi.org/10.24171/j.phrp.2020.11.3.08

Fazrida, F., Khan, P., Mohammed, N., Hafizah, N., \& Harith, M. (2018). The Relationship Between the Impacts of Telecommuting Engagement and Employee Performance in Oil and Gas Industry in Kuantan, Pahang. Malaysian Journal of Social Sciences and Humanities.

Greenhaus, J. H., Collins, K. M., \& Shaw, J. D. (2003). The relation between work-family balance and quality of life. Journal of Vocational Behavior. https://doi.org/10.1016/S0001-8791(02)00042-8

Hamid, M., Wahab, S., Hosna, A., Hasanat, M., \& Kamruzzaman, M. (2020). Impact of Coronavirus (COVID-19) and Employees' Reaction to Changes on Employee Performance of Bangladesh. The International Journal Of Business \& Management, 8(8). https://doi.org/10.24940/theijbm/2020/v8/i8/bm2008-013

Irawanto, D. W., Noermiyati, \& Primasari, D. (2015). The Effect of Occupational Stress on Work Performance of Female Employees: Study in Indonesia. Asia-Pacific Journal of Management Research and Innovation. https://doi.org/10.1177/2319510x15602970

Karia, N., Zainuddin, Y., \& Asaari, A. H. M. H. (2003). PERCEPTIONS OF HUMAN RESOURCES MANAGERS ON TELECOMMUTING CONCEPT: Implementation in Malaysian Firms. Gadjah Mada International Journal of Business. 
https://doi.org/10.22146/gamaijb.5395

Kazmi, R., Amjad, S., \& Khan, D. (2008). Occupational stress and its effect on job performance. A case study of medical house officers of district Abbottabad. Journal of Ayub Medical College, Abbottabad: JAMC.

Khoshnaw, S., \& Alavi, H. (2020). Examining the Interrelation Between Job Autonomy and Job Performance: A Critical Literature Review. Multidisciplinary Aspects of Production Engineering. https://doi.org/10.2478/mape-2020-0051

Liu, P., Wang, X., Li, A., \& Zhou, L. (2019). Predicting work-family balance: a new perspective on person-environment fit. Frontiers in Microbiology.

https://doi.org/10.3389/fpsyg.2019.01804

Mahdi, M. M. (2012). Telecommuting From The Company Perspective: Employer Intention to Implement Telecommuting.

Mann, S., \& Holdsworth, L. (2003). The psychological impact of teleworking: Stress, emotions and health. New Technology, Work and Employment. https://doi.org/10.1111/1468005X.00121

Maulidiyah, N. (2019). The Influence of Self Esteem and Job Stress on Employees Performance by Job Satisfaction as An Intervening Variable in PT Binor Karya Mandiri Paiton Probolinggo. Journal Of Management Info, 6(1), 13-16.

https://doi.org/10.31580/jmi.v6i1.490

Mendoza, S. (2020). The Relationship Between Telecommuting and Occupational Stressors of Nonprofit Professionals. Retrieved 8 January 2021, from https://scholarworks.calstate.edu/concern/theses/cc08hj667

Ministry of Health Malaysia. (2020). Covid-19. http://covid-19.moh.gov.my/

Muda, I., Rafiki, A., \& Harahap, M. R. (2014). Factors Influencing Employees ' Performance : A Study on the Islamic Banks in Indonesia. International Journal of Business and Social Sience.

Mumin, N. (2020). Are Malaysians Ready For Telecommuting? A Case Of Covid-19 Movement Control Order. Journal Of Critical Reviews , 7 (2394-5125

Munusamy, T. (2016). Influence of Teleworking Acceptance on Employee's Work Life in Malaysia's ICT Sector. International Journal Of Accounting \& Business Management, Vol. 4 (No.2)(2289-4519). https://doi.org/10.24924/ijabm/2016.11/v4.iss2/146.158

Onyemaechi, U., Chinyere, U. P., \& Emmanuel, U. (2018). Impact of Telecommuting on Employees' Performance. Journal of Economics and Management Sciences. https://doi.org/10.30560/jems.v1n3p54

Practical Guide on Teleworking during the COVID-19 pandemic and beyond. (2021). Retrieved 9 February 2021, from https://www.ilo.org/travail/info/publications/WCMS_751232/lang--en/index.htm

Pradhan, R., \& Jena, L. (2016). Employee Performance at Workplace: Conceptual Model and Empirical Validation. Business Perspectives And Research, 5(1), 69-85. https://doi.org/10.1177/2278533716671630

Rizwan, M., Jamil, M. I., Shahid, U., Saeedi, H. M. A., Faisal, N., Islam, Z. ul, Qadeer, A., \& Mateen, A. (2014). The Impact of the Job Stress, Job Autonomy and Working Conditions on Employee Satisfaction. International Journal of Human Resource Studies. https://doi.org/10.5296/ijhrs.v4i2.5907

Sahni, D. J. (2020). Impact of COVID-19 on Employee Behavior: Stress and Coping Mechanism During WFH (Work From Home) Among Service Industry Employees. International Journal of Operations Management. https://doi.org/10.18775//ijom.2757- 
0509.2020.11.4004

Saragih, S. (2011). The Effects of Job Autonomy on Work Outcomes: Self Efficacy as an Intervening Variable. International Research Journal Of Business Studies, 4(3), 203-215. https://doi.org/10.21632/irjbs.4.3.203-215

Shereen, M. A., Khan, S., Kazmi, A., Bashir, N., \& Siddique, R. (2020). COVID-19 infection: Origin, transmission, and characteristics of human coronaviruses. In Journal of Advanced Research. https://doi.org/10.1016/j.jare.2020.03.005

Tony, S. (2011), Teleworking and its effectiveness on Work-Life Balance, Munich, GRIN Verlag, https://www.grin.com/document/271564

Singhal, T. (2020). A Review of Coronavirus Disease-2019 (COVID-19). In Indian Journal of Pediatrics. https://doi.org/10.1007/s12098-020-03263-6

Who.int. (2021). Coronavirus. [online] Available at: <https://www.who.int/healthtopics/coronavirus> [Accessed 9 February 2021].

Wolor, C. W., Kurnianti, D., Zahra, S. F., \& Martono, S. (2020). The importance of work-life balance on employee performance millennial generation in Indonesia. Journal of Critical Reviews. https://doi.org/10.31838/jcr.07.09.203

Wolor, C. W., Solikhah, S., Fidhyallah, N. F., \& Lestari, D. P. (2020). Effectiveness of E-Training, E-Leadership, and Work Life Balance on Employee Performance during COVID-19. Journal of Asian Finance, Economics and Business. https://doi.org/10.13106/jafeb.2020.vol7.no10.443

Ye, L. (2012). Telecommuting: Implementation for Success.

Zhang, W. R., Wang, K., Yin, L., Zhao, W. F., Xue, Q., Peng, M., Min, B. Q., Tian, Q., Leng, H. X., Du, J. L., Chang, H., Yang, Y., Li, W., Shangguan, F. F., Yan, T. Y., Dong, H. Q., Han, Y., Wang, Y. P., Cosci, F., \& Wang, H. X. (2020). Mental Health and Psychosocial Problems of Medical Health Workers during the COVID-19 Epidemic in China. Psychotherapy and Psychosomatics. https://doi.org/10.1159/000507639 